\title{
In(compatibility) of intravenous drugs in critical units: adult cohort
}

\author{
In(compatibilidade) de medicamentos intravenosos em unidades críticas: coorte de adultos \\ In(compatibilidad) de medicamentos intravenosos en unidades críticas: cohorte de adultos
}

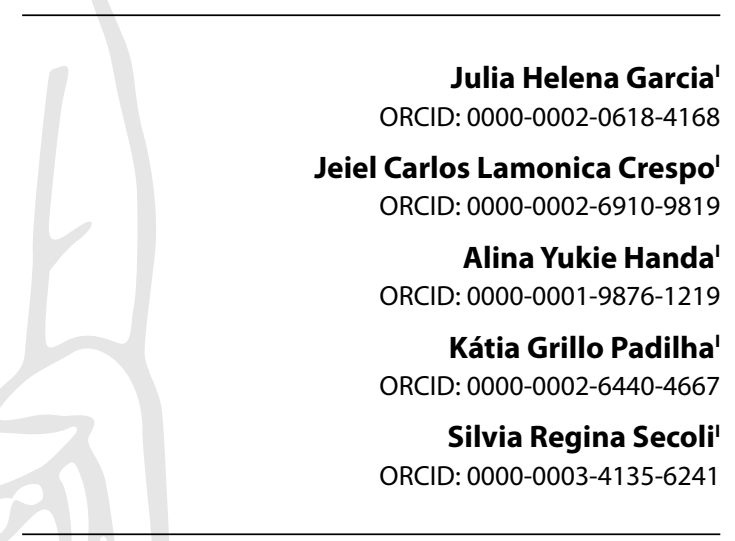

'Universidade de São Paulo. São Paulo, São Paulo, Brazil.

How to cite this article:

Garcia JH, Crespo JCL, Handa AY, Padilha KG, Secoli SR. In(compatibility) of intravenous drugs in critical units: adult cohort. Rev Bras Enferm. 2021;74(2):e20200501. https://doi.org/10.1590/0034-7167-2020-0501

\section{Corresponding author:}

Julia Helena Garcia

E-mail:jhgmogi@yahoo.com.br

EDITOR IN CHIEF: Dulce Barbosa ASSOCIATE EDITOR: Mitzy Reichembach

Submission: $07-16-2020$

Approval: 11-01-2020

\begin{abstract}
Objectives: To analyze potential (in)compatibilities of intravenous drugs based on the scheduling prepared by the nursing team. Methods: historic cohort (retrospective) with 110 adults in critical units. Intravenous medications were identified concomitantly, whose pairs were analyzed for (in) compatibility using the screening system Trissel' $\mathrm{s}^{\mathrm{TM}} 2$ Compatibility IVMicromedex 2.0. Parametric and non-parametric statistic were used according to the nature of the variable. Results: 565 pairs of drugs were identified. Of these, $44.9 \%$ were compatible; and $8.8 \%$, potentially incompatible. Most potentially incompatible pairs involved substances with alkaline $\mathrm{pH}$ such as phenytoin (32\%) and sodium bicarbonate $(8 \%)$ and weak acids such as midazolam (12\%) and dobutamine (6\%), which could result in precipitate formation. Conclusions: almost half of the mixtures simultaneously administrated was compatible, which indirectly reflects in the organized work between the nursing team and the clinical pharmaceutic in the discussions and decisions related to time scheduling.

Descriptors: Intravenous Administration; Incompatibility of Drugs; Intensive Care Units; Critical Care Nursing; Nursing Education.
\end{abstract}

\section{RESUMO}

Objetivos: analisar as (in)compatibilidades potenciais de medicamentos intravenosos com base no aprazamento de horários realizado pela equipe de enfermagem. Métodos: coorte histórica (retrospectiva) com 110 adultos de unidades críticas. Identificaram-se medicamentos intravenosos aprazados de modo concomitante, cujas duplas foram analisadas quanto à (in) compatibilidade por meio do sistema de screening Trissel's $\mathrm{s}^{\mathrm{TM}} 2$ Compatibility IV-Micromedex 2.0. Utilizou-se estatística paramétrica e não paramétrica segundo natureza da variável. Resultados: identificaram-se 565 duplas de medicamentos. Destas, $44,9 \%$ foram compatíveis; e $8,8 \%$, potencialmente incompatíveis. A maioria das duplas potencialmente incompatíveis envolveu substâncias com pH alcalino como fenitoína (32\%) e bicarbonato de sódio (8\%) e ácidos fracos como midazolam (12\%) e dobutamina (6\%), as quais poderiam resultar em precipitação. Conclusões: quase metade das misturas aprazadas simultaneamente foi compatível, aspecto que, indiretamente, reflete o trabalho orquestrado entre a equipe de enfermagem e $o$ farmacêutico clínico nas discussões e decisões acerca do aprazamento de horários. Descritores: Administração Intravenosa; Incompatibilidade de Medicamentos; Unidades de Terapia Intensiva; Enfermagem de Cuidados Críticos; Educação em Enfermagem.

\section{RESUMEN}

Objetivos: analizar las (in)compatibilidades potenciales de medicamentos intravenosos basado en el aplazamiento de horarios realizado por equipo de enfermería. Métodos: cohorte histórica (retrospectiva) con 110 adultos de unidades críticas. Identificaron medicamentos intravenosos aplazados de modo concomitante, cuyas duplas han analizadas cuanto a la (in)compatibilidad por medio del sistema de screening Trissel's ${ }^{T M} 2$ Compatibility IV-Micromedex 2.0. Utilizó estadística paramétrica y no paramétrica segundo naturaleza de la variable. Resultados: identificaron 565 duplas de medicamentos. De estas, $44,9 \%$ compatibles; $y 8,8 \%$, potencialmente incompatibles. Mayoría de las duplas potencialmente incompatibles envolvió substancias con $\mathrm{pH}$ alcalino como fenitoína (32\%) y bicarbonato de sodio (8\%) y ácidos débiles como midazolam (12\%) y dobutamina (6\%), las cuales podrían resultar en precipitación. Conclusiones: casi mitad de las misturas aplazadas simultáneamente fue compatible, aspecto que, indirectamente, refleja el trabajo orquestado entre el equipo de enfermería y el farmacéutico clínico en las discusiones y decisiones acerca del aplazamiento de horarios.

Descriptores: Administración Intravenosa; Incompatibilidad de Medicamentos; Unidades de Cuidados Intensivos; Enfermería de Cuidados Críticos; Educación en Enfermería. 


\section{INTRODUCTION}

In different assistance scenarios, the safe use of medications is considered, by the World Health Organization (WHO), the third global challenge within the scope of the patient safety. Costs related to damage caused by Medication Errors (ME) are worldly estimate in US\$ 42 billion a year ${ }^{(1)}$. Unsafe practices related to drug administration, including infusion of incompatible intravenous drugs (IV), represent one of the most drug-related adverse events (AME) more frequent during hospitalization, and can result in irreversible damages, which most of the time are avoidable ${ }^{(2)}$.

Incompatibility between medications (IN) occurs when two or more drugs are combined in the same solution or receptacle and cause an adverse physic-chemical phenomenon, whose final product can show modification in its physical state ${ }^{(3)}$. Simultaneous infusions of incompatible medications can result in the administration of underdose of drugs; in obstruction of catheters, with consequent loss of intravenous device; in the formation of precipitates that can cause phlebitis or pulmonary thromboembolism; in the evolution to septic conditions; or death ${ }^{(4-8)}$. This way, an IN can compromise the therapeutic efficacy of the drug and affect the clinical stability of critical patients, especially because many drugs have dose-dependent effects ${ }^{(7,9)}$.

Critical patients are highly vulnerable to IN. The severity and instability of clinical conditions, the complexity of therapeutic regime, the coadministration of drugs with different osmolarity and hydrogen potential $(\mathrm{pH})$, superimposed on the limited number of venous accesses or catheter routes, contribute to the occurrence of $\mathbf{I N}^{(4-6,10-13)}$.

In addition, there is the problem with medication administration schedules concurrently ${ }^{(10,14)}$. Studies show that scheduling performed by the nursing team describe a concentration of drugs in certain schedules, which seems related to the institutional routine. Regardless of the route of administration or pharmacological action, medication administration schedules seem to occur invariably in different service ${ }^{(13,15-16)}$. This practice to adopting standard schedules, usually even hours (h) - 8, 10, 12, 14, 16, 18, 20, 22, 0, 2, 4, and 6h-, distant from shift changes and visiting hours may cause $I N$, since variables that interfere with its occurrence are disregarded, such as the $\mathrm{pH}$ of medicines, manufacturers of products, type of diluent and infusion, final concentration of the mixture, time of contact between drugs, conditions for preparing medicines (temperature and light) and the use of a multi-lumen device (e.g., Y $)^{(14)}$.

Due to the importance of drugs administration scheduling in the precipitate formation of $\mathrm{IN}$, and due to the leadership of nursing team, the present study was elaborated.

\section{OBJECTIVES}

Tp analyze potential (in)compatibilities of intravenous drugs (IPM) based on the scheduling prepared by the nursing team when admitting and releasing patients hospitalized in critical care units.

\section{METHODS}

\section{Ethical aspect}

This survey is part of the study "Patients Safety in Intensive Care Units", which goal was analyzing the influence of distinct variables (patients, human resources, safety culture) in the occurrence of adverse events in critical units ${ }^{(17)}$. This way, the project is in accordance with the Guidelines of the Resolution 466/12 of National Health Council (CNS), being approved by the Research Ethics Committee of the Academic Hospital of São Paulo University (HU-USP).

\section{Design, period and place of study}

The study consists of a historic cohort (retrospective) of adult patients hospitalized in critical unities (Intensive Care Unit - ICU; and Semi-Intensive - SI) of an Academic Hospital in the city of São Paulo. This is a general hospital, which medical and hospital care has medium complexity. The critical unities, dedicate to adult care submitted to clinic and/or surgical care, have the total of 20 beds, 12 of which are for ICU, and 8 are for $\mathrm{SI}^{(18)}$.

The elaboration of this observational study was sustained by the Strengthening the Reporting of Observational Studies in Epidemiology (STROBE) guidelines.

\section{Population or sample; criteria of inclusion and exclusion}

The consecutive sampling was composed by 110 adult patients ( $\geq 18$ years), which used two or more intravenous drugs, who were hospitalized in the period of May to June 2012, with permanence time at ICU or SI higher or equal to 72 hours. The records of patients whose prescription data were incomplete were excluded.

\section{Study protocol}

Data was obtained by consulting the original study database of 2015, which allowed the extraction of demographic variables (gender, age), clinics (number of comorbidities, origin, hospitalization unit, type of hospitalization, Simplified Acute Physiology Score II-SAPSII), clinical evolution (medical discharge condition [Survivor or death], Nursing Activities Score - NAS), and variables related to therapeutic regime (number of prescribers, number of drugs prescribed, name of the drugs, scheduling, and day of the prescription [admission and discharge]).

Through medical prescription, IV drugs were simultaneously scheduled (same time), which formed pairs whose (in)compatibility was analyzed. Identifying the (in)compatibility, it was assumed that all IV drugs scheduled at the same time were coadministered in the same route, regardless the number of venous devices. All scheduled drugs were analyzed and administered continuous or intermittently in a Y-device, except crystalloid/colloid solutions and parenteral nutrition.

(In)compatibility was verified through the online software Trissel's $\mathrm{s}^{\mathrm{T}} 2$ Compatibility IV, hosted in the Micromedex 2.0 database, accessed through the portal CAPES - Brazilian Federal Agency for Support and Evaluation of Higher Education ${ }^{(19)}$.

Drug pairs were analyzed for (in)compatibility in method and infusion by Y-devices and classified as "incompatible", "variable compatibility" and "untested drugs". Medicines that show physical-chemical alteration when mixed during infusion in a Y-device are called "incompatible"; "variable compatibility" is attributed when there is a divergence in the results of compatibility between drugs supplied by different manufacturers; and "untested drugs" are those whose drugs have not been tested ${ }^{(20)}$. 
Potential incompatibility between drugs (IPM) was considered to be the theoretical possibility of altering the compatibility of drugs resulting from their simultaneous infusion by $Y$-devices.

A potential incompatibility between the drugs (IPM) and the theoretical possibility of altering the compatibility of such drugs were considered, due to the simultaneous infusion of these by Y-devices.

\section{Analysis of results and statistics}

The software R 3.5.1 was used, and the level of significance was established as 5\%. In statistic processing, categories variables were presented in tables and graphic (absolute and relative frequencies). For quantitative variables, average and standard deviation (SD) were calculated. Average values were compared by the Wilcoxon, McNemar, and paired T tests. In inferential analysis, data distribution was tested for normality for the selection of parametric or non-parametric tests.

\section{RESULTS}

\section{Patients' characteristics}

Most of the patients was male $(52.7 \%$; $\mathrm{n}=58$ ); patients originated from critical units, operating rooms or first-aid posts (87.2\%; $n=96)$, and hospitalized in ICU $(77.3 \% ; n=85)$, with clinical diagnosis $(61 \% ; n=67)$. The average age and length of hospital stay were 62.9 years $( \pm 16.3)$ and 7.2 days $( \pm 4.7)$, respectively. SAPSII score was $48.6( \pm 24.9)$; and mortality rate was $14.6 \%(n=16)$ (Table 1$)$.

Table 1 - Demographic, clinical and progress characteristics of critical patients - 2015, Academic Hospital, São Paulo, São Paulo, Brazil, ( $N=110)$

\begin{tabular}{|c|c|c|}
\hline \multirow{2}{*}{$\begin{array}{l}\text { Demographic, clinical and } \\
\text { progress variables }\end{array}$} & \multicolumn{2}{|c|}{$\mathbf{N}=110$} \\
\hline & n (\%) & Average ( \pm SD) \\
\hline \multicolumn{3}{|l|}{ Gender } \\
\hline Masculine & $58(52.7)$ & \\
\hline Feminine & $52(47.3)$ & \\
\hline Age & & $62.9(16.3)$ \\
\hline Number of comorbidities & & $2.3( \pm 1.8)$ \\
\hline \multicolumn{3}{|l|}{ Origin } \\
\hline First-aid Post & 48 (43.6) & \\
\hline ICU, SICU and Operating room & $48(43.6)$ & \\
\hline Infirmary & $14(12.8)$ & \\
\hline \multicolumn{3}{|l|}{ Place of hospitalization } \\
\hline ICU & $85(77.3)$ & \\
\hline SICU & $25(22.7)$ & \\
\hline \multicolumn{3}{|l|}{ Type of hospitalization } \\
\hline Clinic & $67(61.0)$ & \\
\hline Surgical & $43(39.0)$ & \\
\hline Length of stay & & $7.2( \pm 4.7)$ \\
\hline SAPSII & & $48.6( \pm 24.9)$ \\
\hline \multicolumn{3}{|l|}{ Discharge condition } \\
\hline Survivor & $94(85.4)$ & \\
\hline Not survivor & $16(14.6)$ & \\
\hline
\end{tabular}

\section{Simultaneous drug infusions: admission and discharge}

Of the total sample, $41.8 \%(n=46)$ presented simultaneous infusions of drugs that resulted in IPM. Most of these $(71.8 \% ; n$ $=33)$ presented incompatibility upon admission; $6.5 \%(n=3)$ at discharge; and $21.7 \%(n=10)$ on both days of analysis.

Admission had an average of $1.8( \pm 1,1)$ pairs of incompatible drugs; and $2.3( \pm 1,5)$ pairs at the moment of the patient's discharge. Both days the average was $1.7( \pm 0,5)$. A significant difference between days was not observed ( $p=0.796$ ) (paired T-test).

There was an increased number of prescribed drugs, prescribers, vascular devices, and increased workload in admission compared to the discharge day (Table 2).

Table 2 - Therapeutic and progress characteristics of critical patients - 2015, Academic Hospital, São Paulo, São Paulo, Brazil, ( $N=110)$

\begin{tabular}{|c|c|c|c|c|c|}
\hline \multirow[b]{2}{*}{$\begin{array}{l}\text { Variables related to therapeutic } \\
\text { and progress regime }\end{array}$} & \multicolumn{2}{|c|}{ Admission } & \multicolumn{2}{|c|}{ Discharge } & \multirow[b]{2}{*}{$p$ value } \\
\hline & n (\%) & $\begin{array}{c}\text { Average } \\
( \pm D P)\end{array}$ & n (\%) & $\begin{array}{l}\text { Average } \\
( \pm \text { DP) }\end{array}$ & \\
\hline Number of prescribed drugs & & $6.1( \pm 2.5)$ & & $3.5( \pm 2.4)$ & $\leq 0.001^{*}$ \\
\hline Number of prescribers & & $1.7( \pm 0.8)$ & & $1.2( \pm 0.5)$ & $\leq 0.001^{* *}$ \\
\hline Vascular devices & & $1.9( \pm 0.7)$ & & $1.3( \pm 0.5)$ & $\leq 0.001^{* *}$ \\
\hline Drugs continuously infused & $66(60 \%)$ & & 21 (19\%) & & $\leq 0.001^{* * *}$ \\
\hline Drugs intermittently infused & $110(100 \%)$ & & $98(89 \%)$ & & $=0.001 * * *$ \\
\hline NAS & & $56.1( \pm 14.5)$ & & $47.5( \pm 11.4)$ & $\leq 0.001^{*}$ \\
\hline
\end{tabular}

\section{Intravenous drugs scheduling}

3,772 IV drug doses were scheduled. Most of them (69.5\%; $\mathrm{n}$ $=2,625)$ occurred when the patient was admitted and, among these, half of the doses $(51 \% ; n=1,337)$ was scheduled in the evening shift ( $7 \mathrm{pm}$ to $7 \mathrm{am}$ ). Upon discharge, more than half of the doses $(56.3 \% ; n=589)$ was schedule in day shift ( 7 am to $7 \mathrm{pm})$.

Analyzing the simultaneous scheduling of medications, 565 distinct pairs were identified. Among them, almost half (44.9\%; $n=254)$ was considered compatible; $26.1 \%(n=147)$ were classified as untested medication; $11.4 \%(n=64)$ presented variable compatibility; $8.8 \%(n=50)$ resulted in "Unavailable information", and $8.8 \%(n=50)$ were incompatible.

In "Unavailable information" group, drugs that were not identified in the base were included, such as sodium dipyrone (78\%; $n=39)$; glucose $50 \%(14 \% ; n=7)$ and terlipressin $(8 \% ; n=4)$.

Upon admission, the pairs of incompatible drugs were scheduled, mostly, at $10 \mathrm{am}(32 \% ; n=17)$ and $4 \mathrm{pm}(32 \% ; n=17)$. Upon discharge, scheduling was more frequently at 6 am $(14 \% ; n=7)$ and 8 am $(12 \% ; n=6)$ (Figure 1).

\section{(In)compatibilities of intravenous drugs}

The 50 pairs classified as incompatible were built by infused medications continuously $\times$ intermittently $(52 \%$; $n=26)$, such as mixtures involving sedatives and vasoactive drugs with antibiotics, corticosteroids and diuretics; then, intermittently $\times$ intermittently $(42 \%$; $n=21$ ), such as furosemide and ondansetron; and continuously $x$ continuously $(6 \% ; n=3)$, as dobutamine $\times$ piperacillin + tazobactam. 


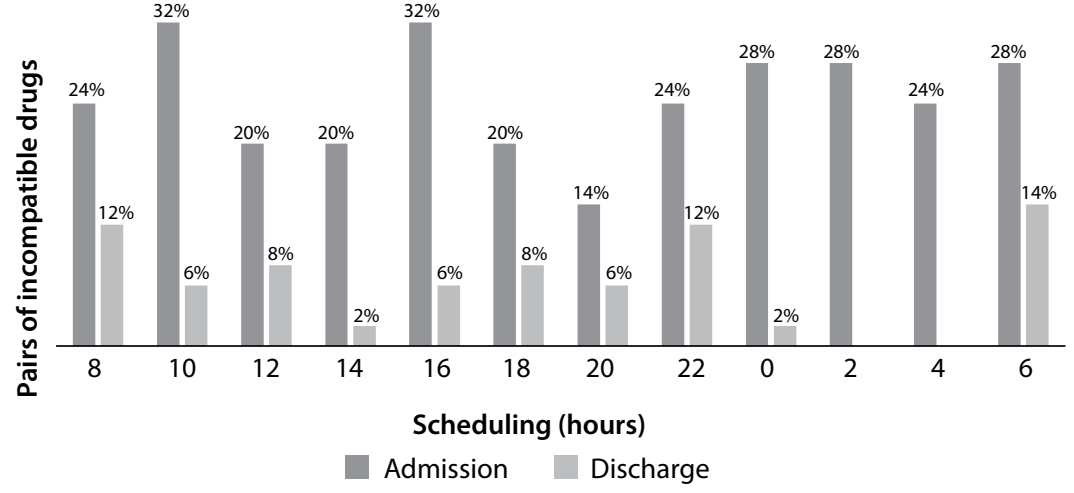

Figure 1 - Infusion schedule for incompatible medication pairs, related to the day they were administered — 2015, Academic Hospital, São Paulo, São Paulo, Brazil, ( $N=110)$

\section{DISCUSSION}

\section{Potential incompatibility between drugs}

The administration of IV drugs with simultaneous schedules in critical units, which included the analysis of 3,772 doses, was higher upon the admission of the patient and preferentially occurred from 10 am to $4 \mathrm{pm}$. Almost half of pairs of infused drugs was compatible (44.9\%). Among the incompatible $(8,8 \%)$, drugs with extreme $\mathrm{pH}(4.5 \leq \mathrm{pH} \geq 12.0)$ were the most involved in the phenomenon, which would potentially cause precipitate reactions.

In this cohort, the predominance of IV drugs

In the pairs, $40 \%(\mathrm{n}=20)$ had substances with basic $\mathrm{pH}$, such as phenytoin ( $32 \% ; n=16)$ and sodium bicarbonate $(8 \% ; n=4)$; and weak acids, such as midazolam $(12 \% ; n=6)$ and dobutamine $(6 \% ; n=3)$.

The combination midazolam $\times$ omeprazole was the most frequent in patients $(23.9 \% ; n=11)$, followed by sodium bicarbonate $x$ norepinephrine $(13 \% ; n=6)$ and dobutamine $\times$ sodium ceftriaxone $10.8 \%(n=5)$. The antibiotics ceftriaxone, clindamycin, piperacillin + tazobactam and cefepime, combined with each other or with other substances, had a frequency of $45.6 \%(n=26)$ (Table 3$)$.

The reactions resulting from the IMP identified based on the schedule could result in precipitate formation $(50 \% ; n=25)$, particle formation and/or color change (20\%; $n=10)$; turbidity $(14 \% ; n=$ $7)$; chemical decomposition ( $6 \% ; n=3)$; appearance of fog ( $4 \% ; n$ $=2)$, formation of free oil in the emulsion (4\%; $n=2)$ and change in color $(2 \% ; n=1)$.

Phenytoin coadministered with 16 different drugs - among the alkaline, furosemide, imipenem + cisplatin and thiopental; and acids, ceftriaxone, clindamycin, dobutamine, dopamine, fentanyl, insulin, methylprednisolone, midazolam, sodium nitroprusside, piperacillin + tazobactam, ranitidine, thiamine, vancomycin - could result in precipitate formation in all mixtures. upon admission can be attributed to the clinical severity of the patient, expressed by the highest mortality score (SAPSII), average age ( $>60$ years), higher number of prescribers and presence of IV polypharmacy. Most of the patients $(60 \%)$ received continuous infused drugs by means of a limited number of venous access (1.9 average), which aspect, in theory, could increase the possibility of potential incompatibility between drugs. The insufficient number of IV devices, often seen in critical units ${ }^{(21)}$, represent a risk for IPM, especially if superimposed on the infusion mode ${ }^{(5)}$.

In accordance with other authors, the continuous infusion predominated in the sample (5-6,11,14,22-23) $^{\text {The }}$ This very useful way of administration in critical care context was preferably used for short biological half-life drugs (catecholamines) or for those who require constant blood concentration (fentanyl + midazolam). This strategy that promotes the mixture of medications, usually for a contact time of hours, may result in IPM, especially in the presence of a mixture of agents with acid and alkaline $\mathrm{pH}$, some evidenced in this cohort. Drug pairs continuously infused and usually involved in IPM, were used, mainly for patient sedation, a plausible finding with the care environment and recommended by international guidelines ${ }^{(24)}$.

Table 3 - Fifteen more frequent pairs of potentially incompatible drugs in critical patients, and the respective potential physical-chemical alterations 2015, Academic Hospital, São Paulo, São Paulo, Brazil, ( $N=110)$

Potentially incompatible drug pairs (pH)
Potential physic-chemical alterations

Change in color and precipitate formation Chemical decomposition

Particle formation and/or change in color

Chemical decomposition

Change in color

Particle formation and/or change in color

Precipitate formation

Particle formation and/or change in color

Particle formation and/or change in color

Particle formation and/or change in color

Turbidity after one hour and precipitate formation

Turbidity

Fog and particle formation

Turbidity

Precipitate formation
Patients with double prescription n (\%)
Sodium bicarbonate $(\mathrm{pH} 7.0-8.5) \times$ Amiodarone $(\mathrm{pH} 4.0)$

Dobutamine $(\mathrm{pH} 2.5-5.5) \times$ Piperacillin + Tazobactam $(\mathrm{pH} 1.8-3.0)$

Piperacillin + Tazobactam $(\mathrm{pH} 1.8-3.0) \times$ Insulin $(\mathrm{pH} 7.0-7.8)$

Metoclopramide $(\mathrm{pH} 4.5-6.5) \times$ Cefepime $(\mathrm{pH} 4.0-6.0)$

Phenytoin $(\mathrm{pH} \mathrm{12.0)} \times$ Furosemide $(\mathrm{pH} 8.0-9.3)$
$11(23.9 \%)$
$6(13 \%)$
$5(10.8 \%)$
$5(10.8 \%)$
$4(8.7 \%)$
$4(8.7 \%)$
$3(6.5 \%)$
$3(6.5 \%)$
$3(6.5 \%)$
$3(6.5 \%)$
$2(4.3 \%)$
$2(4.3 \%)$
$2(4.3 \%)$
$2(4.3 \%)$
$2(4.3 \%)$

Note: $p H:$ hydrogen potential. 
Another aspect that deserves special consideration is regarding the possibility of IPM, specially for the direct involvement of the nurse, concerns the schedules when the medications were programmed simultaneously. Most of the doses were scheduled to $10 \mathrm{am}, 4 \mathrm{pm}$, and $2 \mathrm{am}$ and $6 \mathrm{pm}$. The concentration of drugs administration at the times analyzed (admission and discharge), was corroborated by previous studies conducted in critical units, which, similar to this cohort, also did not observe the use of odd hours as a routine for drugs administration ${ }^{(2,13,22,25-26)}$. The standardization of schedules, even though it favors the organization of the service and is adapted to institutional routines such as logistics for the distribution of medicines by the pharmacy and nursing assistance, can limit the analysis and critical judgment of the nurse regarding the peak of action, drugs physical- chemistry characteristics, drug interactions and potential IPMs ${ }^{(13-15,25)}$.

Regarding the performance of the organization of the schedule, almost half of the paired infused drugs was compatible. This dissonant finding from previous studies conducted in ICU, which indicate lower compatibility frequency $(21.5 \%)^{(11)}$, may be attributed to some scenario particularities of the study. At investigated units, the clinical pharmacist evaluates the medical prescriptions daily, in order to identify potential issues related to the drugs, such as drugs interactions and IPM. Interventions performed by pharmacists, which include adjustments to the programmed schedule of prescriptions, alteration of the medication infusion mode or a new suggestion for the combination of pairs in the venous access devices, may contribute to the reduction of $\mathrm{IPM}^{(11,27)}$. Additionally, there is the IV drugs dilution manual and illustrative (in)compatibility guidelines with most frequently used agents at the nursing post, which can be consulted at the moment of scheduling and administration.

(In)compatibility evaluation represents one of the 13 rights of medication administration that, within ICU, indicate one of the main points for the complexity of the therapy. The existence of mistakes or negligence in the evaluation of this attribute will result in the violation of basic principles of professional responsibility ${ }^{(28)}$. Consult manuals regarding IPM, double-checking the schedule (nurse and pharmacist), and use of millilumens devices are tools that may help in the prevention and reduction of IPM events ${ }^{(22,29)}$.

In this study, although less than $10 \%$ of simultaneous infusions had been classified as incompatible, the potential adverse impact needs to be considered, especially because half of them could have precipitate formation as a consequence. Precipitate phenomenon is due mainly because the cations and anions combination existing in the solutions, which results in the formation of insoluble solids (precipitate) $^{(30)}$. Thus, precipitate solutions often present microparticles and these may be responsible for the obstruction of venous devices ${ }^{(5,7)}$. A study performed with hemodialysis catheters showed that the composition of the occlusive material included crystalline drug precipitate incorporated in matrices formed by fibrin and blood cell $s^{(31)}$. Particles derivate from IPM may also irritate venous capillaries and contribute to the formation of microthrombi ${ }^{(32)}$. Cases of embolism were attributed to the precipitate of medications ${ }^{(33-34)}$. Although it is difficult to establish the causal relationship between IPM and negative clinical outcomes that can cause irreversible damage to the patient, coadministration of incompatible drugs must be avoided.

Corroborating previous studies, the difference of $\mathrm{pH}$ of the coadministrated substances represented one of the main probable reasons for the occurrence of IPM ${ }^{(14,28,35)}$. The anticonvulsant phenytoin was the agent most often involved in combinations capable of causing precipitate formation. Highly alkaline $\mathrm{pH}(\mathrm{pH} 12)$ and the low solubility of the medication make the mixture of this drug with other agents almost prohibitive ${ }^{(11)}$. However, weak acids, such as fentanyl, dobutamine, dopamine, midazolam, haloperidol, ondansetron and piperacillin + tazobactam, were simultaneously scheduled.

Incompatible pairs that included catecholamines (norepinephrine, dopamine and dobutamine), amiodarone, fentanyl, midazolam and propofol have been previously described ${ }^{(5-6,11-12)}$. Norepinephrine (acid $\mathrm{pH}$ ) was coadministrated mainly with sodium bicarbonate, an alkalinizing electrolyte solution that can lead to the chemical decomposition of the vasopressor due to the alkaline $\mathrm{pH}^{(19)}$. The pair midazolam $\times$ omeprazole (23.9\%), very common in this cohort and reported in the literature ${ }^{(11,13-14,22)}$, can also cause PMI. These findings reinforce the importance of the team's knowledge about the $\mathrm{pH}$ of medicines and IV solutions.

$\mathrm{pH}$ is considered one of the main factors used to maintain the stability of medicines. However, it is able to increase or decrease the speed of chemical reactions evolved in the degradation, especially when the optimum $\mathrm{pH}$ range of the drug is changed in mixtures (for upper or lower limits) $)^{(30,36)}$. Loss of drug stability or degradation, even if identified only through laboratory investigations, is plausible to occur with some aforementioned combinations and may cause ineffectiveness of the drug, reiterating the relevance of the findings in this cohort.

Studies regarding medication (in)compatibility or specific combinations existing in therapeutic regimens used in the clinical context are limited, an aspect that reflects the lack of information on many mixtures, mainly in the national scenario ${ }^{(5-6,11,37-39)}$. Injectable dipyrone is marketed in Brazil for decades, however, information regarding compatibility remains unknown. Furthermore, product instructions and international incompatibility screening systems do not contain data. This aspect that seems irrelevant to manufacturers, may compromise the safety of the patient. IPM risk during coadministration with other drugs may be real, even if unknown, mainly because it is a widely prescribed painkiller ${ }^{(39)}$.

\section{Study limitations}

Although this study reveals valuable information to help to explain practices related to nursing team, within the scope of intravenous therapy, there were limitations that can be overcome in future investigations. The cohort was not designed to evaluate the clinic impact of IPM, such as occlusion or loss of catheters, precipitate formation or degradation of drugs. Despite the nature of retrospective of data, which avoided the identification of the contact time between medications, concentration of solutions, type of diluent, product manufacturers, drug preparation conditions, aspects that interfere with IPM, the findings reflect the practice of a university hospital.

\section{Contributions for the Area}

The double drugs identified integrate therapeutic regimes used in the current daily life of Brazilian critical units. The scheduling dynamics by the nursing team represents a challenge, not only 
due to the number of medications, but also due to the limitation of safe information on the topic.

The addition of the findings of the present study, despite not providing a broad overview of the problem, may contribute to the elucidation of the phenomenon in these units.

\section{CONCLUSIONS}

The organized work between the nursing team and the clinical pharmacist in the discussions and decisions about the scheduling certainly contributed to the greater occurrence of compatible mixtures in this cohort. Despite this, incompatible combinations (8.8\%) predominantly occurred with medications that have extreme $\mathrm{pH}(4.5 \leq \mathrm{pH} \geq 12)$, infused continuously and that integrate therapeutic regimes commonly used in critical units, which aspects illustrate the complex polypharmacy, the limitation of venous accesses, the risk of medications precipitate and, perhaps, the difficulty of the multidisciplinary team to apply the principles of good practices regarding IPMs in this context of critical care.

\section{FUNDING}

To Research Support Foundation of the State of São Paulo FAPESP, for funding the Project "Patient Safety in intensive and semi-intensive care units: the influence of human nursing factors on the occurrence of adverse events", in which this survey is insert.

\section{ACKNOWLEDGEMENT}

To Ricardo Luis Barbosa for making the entire database of the aforementioned research.

\section{REFERENCES}

1. World Health Organization (WHO). Global Patient safety challenge. medication without harm. [Internet]. Geneva: WHO; 2017 [cited 2018 Sep 27]. Available from: https://apps.who.int/iris/bitstream/handle/10665/255263/WHO-HIS-SDS-2017.6-eng.pdf;jsessionid=060E7EB97B61 CF3ADC23C315D911AE99? sequence $=1$

2. Fahimi F, Ariapanah P, Faizi M, Shafaghi B, Namdar R, Ardakani MT. Errors in preparation and administration of intravenous medications in the intensive care unit of a teaching hospital: an observational study. Aust Crit Care. 2008;21(2):110-6. https://doi.org/10.1016/j. aucc.2007.10.004

3. Newton DW. Physicochemical determinants of incompatibility and instability in injectable drug solutions and admixtures. Am J Hosp Pharm. 1978;35(10):1213-22.

4. Secoli SR. Drugs interactions: fundamental aspects for clinical practice nursing. Rev Esc Enferm USP. 2001;35(1):28-34. https://doi. org/10.1590/S0080-62342001000100005 Portuguese.

5. Kanji S, Lam J, Goddard R, Johanson C, Singh A, Petrin L, et al. Inappropriate medication administration practices in Canadian Adult ICUs: a multicenter, cross-sectional observational study. Ann Pharmacother. 2013;47(5):637-43. https://doi.org/10.1345/aph.1R414

6. Kanji S, Goddard R, Donnely R, Mclntyre L, Turgeon A, Coons P, et al. Physical compatibility of drug infusions used in Canadian Intensive Care Units: a program of research. Crit Care Med. 2010;38(9):1890-8. https://doi.org/10.1097/CCM.0b013e3181e8adcc

7. Benlabed M, Perez M, Gaudy R, Genay S, Lannoy D, Barthélémy C, et al. Clinical implications of intravenous drug incompatibilities in critically ill patients. Anaesth Crit Care Pain Med. 2019;38(2):173-80. https://doi.org/10.1016/j.accpm.2018.04.003

8. Benlabed M, Mena AM, Gaudy R, Perez M, Genay S, Hecq JD, et al. Analysis of particulate exposure during continuous drug infusion in critically ill adult patients: a preliminary proof-of concept in vitro study. Intensive Care Med Exp. 2018;6:38. https://doi.org/10.1186/ s40635-018-0205-2

9. Maiguy-Foinard A, Genay S, Lannoy D, Barthélémy C, Lebuffe G, Debaene B, et al. Criteria for choosing an intravenous infusion line intended for multidrug infusion in anaesthesia and intensive care units. Anaesth Crit Care Pain Med. 2017;36(1):53-63. https://doi.org/10.1016/j. accpm.2016.02.007

10. Secoli SR, Pérez-Esquirol E, Heras-Matellán MJ, Vendrell-Bosh L, Ballarín-Alins E. Incompatibilidades em la terapia intravenosa: ¿quéhacer para preveni-las?. Enferm Clín. 2009;19(6):349-53. https://doi.org/10.1016/j.enfcli.2009.07.003 Spanish.

11. Moraes CG, Silva D, Bueno D. Análise de incompatibilidades de medicamentos intravenosos no Centro de Tratamento Intensivo adulto do Hospital das Clínicas de Porto Alegre. Rev HCPA [Internet]. 2011 [ cited 2020 Feb 27];31(1):31-8. Available from: https://seer.ufrgs.br/hcpa/ article/view/14733/11591 Portuguese.

12. Machotka O, Manak J, Kubena A, Vlcek J. Incidence of intravenous drug incompatibilities in intensive care units. Biomed Pap Med Fac Univ Palacky Olomouc Czech Repub. 2015;159(4):652-6. https://doi:10.5507/bp.2014.057

13. Silva LD, Matos GC, Barreto BG, Albuquerque DC. Drug scheduling for nurses in prescriptions at sentinela hospital. Texto Contexto Enferm. 2013;22(3):722-30. https://doi: 10.1590/S0104-07072013000300019.

14. Paes GO, Moreira SO, Moreira MB, Martins TG. Drug incompatibility in the ICU: review of implications in nursing practice. Rev Eletrôn Enferm. 2017;19:a20 https://doi.org/10.5216/ree.v19.38718

15. Amorim FDB, Flores PVP, Bosco PS, Menezes AHB, Alóchio KV. O aprazamento de medicamentos pautados na segurando paciente: um alerta para prática de enfermagem. Rev Enferm UFPE. 2014;8(1):224-8. https://doi.org/10.5205/reuol.4843-39594-1-SM.0801201432 Portuguese. 
16. Fonseca RB, Secoli SR. Drugs used in bone marrow transplantation: a study about combinations of potentially interactive antimicrobials. Rev Esc Enferm USP. 2008;42(4):706-14. https://doi.org/10.1590/S0080-62342008000400013

17. Padilha KG, Barbosa RL, Oliveira EM, Andolhe R, Ducci AJ, Secoli SR Patient safety in Intensive Care Units: development of a research Project. Rev Esc Enferm USP. 2015;49(N-Esp):157-63. https://doi.org/10.1590/S0080-623420150000700022

18. Universidade de São Paulo. Hospital Universitário. Regimento [Internet]. São Paulo; 2012. [cited 2020 Feb 27]. Available from: http://www. hu.usp.br/regimento

19. MICROMEDEX Healthcare Series [Internet]. New York; [2021]. Available from: https://www.ibm.com/br-pt/watson-health/about/ micromedex [cited 2021 Mar 11].

20. Truven Health Analytics. Micromedex solutions ${ }^{\circledR}$. Ann Arbor; $\odot 2014$. Chap.11 - IV compatibility tool. p. 131-45.

21. Fernández-Ruiz M, Carretero A, Díaz D, Fuentes C, González Jl, García-Reyne A, et al. Hospital-wide survey of the adequacy in the number of vascular catheters and catheter lumens. J Hosp Med. 2014;9(1):35-41. https://doi.org/10.1002/jhm.2130

22. Marsilio NR, Silva D, Bueno D. Drug incompatibilities in the adult intensive care unit of a university hospital. Rev Bras Ter Intensiva. 2016;28(2):147-53. https://doi:10.5935/0103-507X.20160029

23. Gaetani M, Frndova H, Seto W, Parshuram, C. Concurrent intravenous drug administration to critically ill children: evaluation of frequency and compatibility. J Crit Care. 2017.41:198-203. https://doi.org/10.1016/j.jcrc.2017.05.027

24. Devlin JW, Skrobik Y, Gélinas C, Needham DM, Slooter AJC, Pandharipande PP et al. Clinical practice guidelines for the prevention and management of pain, agitation/sedation, delirium, immobility, and sleep disruption in adult patients in the ICU. Crit Care Med. 2018;46(9):825-73. https://doi.org/10.1097/CCM.0000000000003299

25. Fontenele RE, Araújo TI. Análise de planejamento dos horários de administração de medicamentos em unidades de terapia intensiva cardiológica. Rev Enferm UERJ [Internet]. 2006 [cited 2020 Feb 27];14(3):342-9. Available from: www.revenf.bvs.br/pdf/reuerj/v14n3/v14n3a03.pdf

26. Fahimi, F, Forough AS, Taghikhani S, Saliminejad L. The rate of physicochemical incompatibilities, administration errors. Factors correlating with nurses' errors. Iran J Pharm Res [Internet]. 2015 [cited 2020 Feb 27];14(Suppl):87-93. Available from: https://www.ncbi.nlm.nih.gov/ pmc/articles/PMC4499430/pdf/ijpr-14-087.pdf

27. Araujo EO, Viapiana M, Domingues EAM, Oliveira GS, Polisel CG. Pharmaceutical interventions in a Intensive Care of a University Hospital. Rev Bras Farm Hosp Serv Saude. 2017;8(3):25-30. https://doi:10.30968/rbfhss.2017.083.005 Portuguese.

28. Belela ASC, Peterlini MAS, Pedreira MLG. Erros de medicação: definições e estratégias de prevenção. Conselho Regional de Enfermagem de São Paulo e Rede Brasileira de Enfermagem e Segurança do Paciente - Polo São Paulo. [Internet]. São Paulo; 2011 [cited 2020 Feb 28]. Available from: https://www.passeidireto.com/arquivo/3881271/erros-de-medicacao-definicoes-e-estrategias-de-prevencao

29. Vijayakumar A, Sharon EV, Teena J, Nobil S, Nazeer I. A clinical study on drug-related problems associated with intravenous drug administration. J Basic Clin Pharm. 2014;5(2):49-53. https://doi.org/10.4103/0976-0105.134984

30. Newton DW. Drug incompatibility chemistry. Am J Health Syst Pharm. 2009;66(4):348-57. https://doi.org/10.2146/ajhp080059

31. Prasad GS, Ledger R, Puntis JWL, Ball PA. Occluding material present in central venous and haemodialysis catheters. BAPN Abstracts. Proc Nutr Soc. 1998;52-7.

32. Hill SE, Heldman LS, Goo ED, Whippo PE, Perkinson JC. Fatal microvascular pulmonary emboli from precipitation of a total nutrient admixture solution. JPEN J Parenter Enteral Nutr. 1996;20(1):81-7. https://doi.org/10.1177/014860719602000181

33. Ott MC, Khoor A, Scolapio JS, Leventhal JP. Pulmonary microcrystalline cellulose deposition from intravenous injection of oral medication in a patient receiving parenteral nutrition. JPEN J Parenter Enteral Nutr. 2003;27(1):91-2. https:// doi.org/10.1177/014860710302700191

34. Buiter HJ, Blaauwgeers JLG, Van der Spoel Jl, Franssen EJ. Erythromycin precipitation in vena femoralis: investigation of crystals found in postmortem material of an intensive care unit patient. Ther Drug Monit. 2008;30(1):125-9. https://doi.org/10.1097/FTD.0b013e31815bf864

35. Nemec K, Kopelent-Frank H, Greif R. Standardization of infusion solutions to reduce the risk of incompatibility. Am J Health Syst Pharm. 2008;65(17):1648-54. https:// doi.org/10.2146/ajhp070471

36. Trissel LA. Drug stability and compatibility issues in drug delivery. Cancer Bull.1990;42:393-8.

37. Kanji S, Lam J, Johanson C, Singh A, Goddard R, Fairbairn J, et al. Systematic review of physical and chemical compatibility of commonly used medications administered by continuous infusion in intensive care units. Crit Care Med. 2010;38(9):1890-8. https://doi.org/10.1097/ CCM.0b013e3181e8adcc

38. Mendes JR, Lopes MCBT, Vancini-Campanharo CR, Okuno MFP, Batista REA. Types and frequency of errors in the preparation and administration of drugs. Einstein (São Paulo). 2018;16(3):eAO4146. https://doi.org/10.1590/S1679-45082018AO4146

39. Leal KDB, Leopoldino RWD, Martins RR, Veríssimo LM. Potential intravenous drug incompatibilities in a pediatric unit. Einstein (São Paulo). 2016;14(2):185-9. https://doi.org/10.1590/S1679-45082016AO3723 